\title{
Evaluasi Kualitatif Program Pendidikan dan Pelatihan Calon Kepala Sekolah Model In-On-In
}

\author{
Dwi Esti Andriani ${ }^{1}$, Dinar Tri Juliyanti ${ }^{1}$, Suyud ${ }^{1}$, Mustiningsih ${ }^{2}$, Arifin ${ }^{3}$ \\ ${ }^{1}$ Universitas Negeri Yogy akarta, Yogyakarta, DIY, Indonesia \\ ${ }^{2}$ Universitas Negeri Malang, Malang, Jawa Timur, Indonesia \\ ${ }^{3}$ Universitas Negeri Gorontalo, Kota Gorontalo, Gorontalo, Indonesia
}

Corresponding author: Dwi Esti Andriani (e-mail: dwi_esti@uny.ac.id)

\begin{abstract}
Abstrak: Penelitian ini bertujuan untuk mengevaluasi program penyiapan calon kepala sekolah dengan model in-on-in. Fokus penelitiannya yaitu pada pelaksanaan pendidikan dan pelatihan (diklat) yang terdiri dari tahap in-service learning 1 (ISL1), on the job learning (OJL), dan in-service learning 2 (ISL2). Penelitian menggunakan pendekatan kualitatif. Pengumpulan data dilakukan dengan wawancara semi terstruktur kepada lulusan program dan studi dokumentasi. Data yang terkumpul kemudian dianalisis secara kualitatif. Kriteria dependabilitas, kredibilitas, transferabilitas, dan komfirmabilitas diterapkan untuk menjamin kualitas data. Hasil penelitian menunjukkan bahwa pengembangan program pendidikan dan pelatihan (diklat) calon kepala sekolah (CKS) di Indonesia secara umum senada dengan trend pengembangan program penyiapan CKS di berbagai negara. Kurikulumnya komperhensif dan koheren yang mengkaitkan antara pengetahuan teoritis yang diberikan melalui pembelajaran di kelas dengan pengetahuan dan keterampilan praktis melalui magang di sekolah pada tahap OJL. Diklat juga telah menerapkan pendekatan pembelajaran orang dewasa dan mengevaluasi tingkat penguasaan kompetensi peserta diklat. Model diklat ini dirasakan lulusan telah mendukung penguasaan kompetensi kepala sekolah yang mereka butuhkan saat menjabat. Namun demikian, hasil evaluasi menunjukkan bahwa masih terdapat beberapa aspek dari komponen pelaksanaan diklat yang perlu ditingkatkan. Aspek tersebut yaitu: relevansi kurikulum dengan tugas pekerjaan dan tanggung jawab kepala sekolah saat ini, kualitas me ntor dan pementorannya saat peserta melaksanakan magang di sekolah.
\end{abstract}

Kata Kunci: evaluasi program, pelatihan calon kepala sekolah, kepala sekolah

\section{Qualitative Evaluation of Training Program for Prospective Principals Applying In-On-In Model}

Abstract: This study aims to evaluate the training program for prospective principals applying the in-on-in learning model. The focus is on the implementation phase of the in-on-in, which is the in-service learning 1 (ISL1), on-the job learning (OJL), and in-service learning 2 (ISL2). This study applied a qualitative approach. Data were collected using a semi structured interview and document study. The collected data, then, were analyzed using qualitative data analysis methods. Dependability, credibility, transferability, and confirmability criteria are applied to ensure the quality of the data. The results of the study show that the development of the training for prospective school principals in Indonesia is in line with the international trend 
of principal preparation programs. The curriculum is comprehensive and coherent which links the theoretical knowledge delivered face to face in the classroom to practical knowledge and skills learned through internships at the OJL. The training program applied an adult learning approach and evaluated the competency level that the participants achieved. This training model is viewed by graduates to be effective to help them to master the principal competencies they need. However, the results also show that there are still several aspects of the training that need improvement. These aspects include the relevance of the curriculum to the current tasks and responsibilities of the principals, the quality standard of the mentor and mentoring process when participants are doing internships.

Keywords: program evaluation, training for prospective principals, school principal

\section{PENDAHULUAN}

Kepemimpinan sekolah berpengaruh secara signifikan terhadap keefektifan sekolah (Bush, 2007; Bush \& Glover, 2003). Kepemimpinan sekolah diketahui merupakan faktor terbesar kedua yang berpengaruh signifikan pada mutu pembelajaran dan prestasi siswa (Leithwood, Harris, \& Hopkins, 2008). Hasil penelitian ini telah menguatkan urgensi penyelenggaraan program penyiapan kepala sekolah (PPKS) yang efektif di berbagai negara. Terlebih, desentralisasi pendidikan dan manajemen berbasis sekolah yang telah menjadi tren internasional mensyaratkan kepemimpinan sekolah, khususnya kepemimpinan kepala sekolah yang efektif untuk keberhasilan implementasinya (Delaney, 1997; Cranston, 2001; AbuDuhou, 1999).

PPKS bukanlah hal baru, khususnya di negara maju seperti Amerika Serikat. Perkuliahan tentang administrasi pendidikan yang didesain untuk melatih para kepala sekolah menjadi administrator sekolah yang efektif telah dikembangkan pertama kali tahun 1881 di the University of Michigan oleh William T. Pane, mantan pengawas sekolah (Papalewis, 2005). Perkuliahan ini terus berkembang hingga menjadi program studi administrasi pendidikan di pasca sarjana (Oplatka, 2009). Pengembangan PPKS tersebut terus berlanjut seiring perkembangan tuntutan mutu pendidikan yang semakin tinggi dan tantangan pendidikan yang semakin kompleks. Contohnya yaitu program ini telah memanfaatkan standar profesional untuk seorang administrator yang dikembangkan oleh organisasi profesi. Selain itu, program lisensi administrasi untuk menghasilkan calon pemimpin sekolah berbakat yang latar belakangnya bukan pendidikan (Fry, O’Neill, \& Bottoms, 2006).

Di Indonesia, di era sentralistik atau sebelum tahun 2000an, PPKS belum mendapatkan perhatian yang seharusnya. Mayoritas kepala sekolah tidak mendapatkan persiapan yang memadai untuk memangku jabatan kepala sekolah. Pengangkatan mereka umumnya hanya berdasarkan pemenuhan syarat administratif tanpa disertai pembekalan yang memadai 
(Andriani, 2017; OECD/Asian Development Bank, 2015). Akibatnya, mayoritas kepala sekolah di Indonesia tidak menguasi kompetensi yang dibutuhkan untuk menjalankan tugas dan tanggung jawabnya dengan baik (The Education Sector Analytical and Capacity Development Partnership, 2013).

Sejak awal tahun 2000-an ketika desentralisasi pendidikan telah diberlakukan, PPKS mulai mendapatkan perhatian. Model baru PPKS dikenalkan sebagai kerangka acuan bagi pemerintah daerah dalam penyiapan kepala sekolah. Model baru ini menyiapkan kepala sekolah melalui empat tahap yaitu rekrutmen, seleksi, diklat calon kepala sekolah (CKS), dan sertifikasi. Tujuannya adalah untuk menghasilkan CKS yang berkualitas yang dibutuhkan untuk peningkatan mutu sekolah dan prestasi siswa (Kementerian Pendidikan Nasional, 2011). Pada tahun 2013, model ini telah diimplementasikan di 25 kabupaten (Ministry of Education and Culture, 2013) dan menjadi acuan nasional PPKS dengan sedikit modifikasi pada komponen kurikulum diklat CKS-nya.

Sejak diimplementasikan, PPKS di Indonesia belum banyak diteliti (Sumintono, Sheyopuri, Jiang, Misbach, \& Jumintono, 2015). Oleh karenanya, informasi terkait hal ini sangat lah terbatas. Merespon kondisi tersebut, penelitian ini bertujuan untuk mengevaluasi program diklat CKS di propinsi DIY. Suharsimi \& Cepi (2007) mengatakan bahwa evaluasi program penting dilakukan untuk mengetahui ketercapaian tujuan program, mendapatkan informasi mengapa suatu program berhasil atau gagal, dan menentukan tindak lanjut program. Fokus penelitian ini yaitu pada komponen diklat CKS yang terdiri dari tahap in-service learning 1 (ISL1), on the job-learning (OJL), dan in-service training 2 (ISL2).

\subsection{Teori program penyiapan kepala sekolah}

Hasil penelitian yang dilakukan oleh Barbour (2005), Davis \& Hammond (2012) dan Gene, Neill, Betty, David (2003) menunjukkan bahwa keberhasilan program penyiapan CKS ditentukan salah satunya oleh kualitas bakal CKS. Menurut mereka, bakal CKS yang ideal memiliki pemahaman yang baik tentang kurikulum dan pembelajaran, memiliki motivasi untuk menjadi kepala sekolah, serta memiliki keinginan untuk menghasilkan siswa yang berprestasi tinggi. Untuk itu, PPKS perlu menerapkan sistem rekrutmen dan seleksi yang ketat (Davis \& Hammond, 2012; Gene, et al., 2003). Proses seleksi, olehkarenanya, perlu menganalisis secara mendalam prestasi profesional dan kemampuan kepemimpinan calon peserta (Gene, et al., 2003).

Penyelenggara program penyiapan kepala sekolah perlu bekerjasama dengan pemerintah yang membawahi atau membina langung sekolah-sekolah. Mereka mengetahui 
kualitas kepala sekolahyang merekabutuhkan. Mereka, oleh karenanya, perlu dilibatkan dalam penetapan kriteria dan prosedur seleksi, pengembangan program diklat serta penyediaan dan pengalokasian sumber daya yang dibutuhkan program (Gene, et al., 2003). Mereka dapat membantu mengintegrasikan kegiatan program diklat CKS dengan pekerjaan-pekerjaan di sekolah (Davis \& Hammond, 2012).

Tujuan utama PPKS yaitu untuk membekali peserta pengetahuan dan keterampilan yang dibutuhkan mereka agar dapat meningkatkan prestasi belajar siswa. Untuk ini, hasil penelitian menyarankan agar kurikulum PPKS terstandar dan membekali peserta kepemimpinan intruksional, pengembangan organisasi dan manajemen perubahan (Davis \& Hammond, 2012). Selain itu, materi PPKS perlu dikaitkan dengan kurikulum dan pengajaran yang efektif untuk meningkatkan prestasi siswa (Gene, dkk, 2003) Konsekwensinya, materi diklat hendaknya bersifat kekinian dan mengacu pada standar profesional administrasi pendidikan

Untuk mencapai tujuannya, diklat CKS membutuhkan strategi pembelajaran yang efektif. Strategi pembelajaran yang efektif merupakan strategi yang dapat mendorong keaktifan belajar peserta, lebih menekankan praktik daripada teori serta menghubungkan teori dan praktik (Davis \& Hammond, 2012). Dengan kata lain, diklat perlu menerapkan pendekatan pembelajaran yang lebih banyak memberikan pengalaman langsung, berbasis masalah dan otentik. Oleh karenanya, magang merupakan salah satu komponen vital diklat penyiapan kepala sekolah (Davis \& Hammond, 2012; Dodson, 2014; Gene, dkk., 2003).

Magang yang berkualitas perlu direncanakan dengan baik. Hasil studi menyarankan agar peserta magang dapat mendiskusikan dengan kepala sekolah dimana dia akan melaksanakan magang tentang pengalaman lapangan yang dia ingin peroleh. (Davis \& Hammond, 2012; Dodson, 2014). Kegiatan magang hendaknya mencakup observasi dan praktik kepemimpinan sekolah, seperti pembuatan keputusan berbasis sekolah, pemecahan masalah tentang kurikulum dan pembelajaran, pengelolaan keuangan sekolah serta kesempatan untuk melakukan pekerjaan sebagai kepala sekolah sehari-hari (Dodson, 2014; Gene, dkk., 2003). Dalam proses magang, peserta perlu didampingi mentor yang berpengalaman (Davis \& Hammond, 2012; Dodson, 2014). Penilaian capaian pembelajarannya sebaiknya berbasis kinerja yang bisa dilihat dari, misalnya: proyek pembelajaran berbasis masalah dan portofolio kegiatan.

PPKS yang berhasil dapat dinilai dari kualitas lulusannya. Jika efektif, lulusan PPKS memiliki tingkat kepuasan yang tinggi terhadap program yang diikutinya, kepercay aan diri dan efikasi yang tinggi terhadap tugas-tugas administratif serta mampu bekerjasama dengan guru 
untuk meningkatkan proses dan hasil pembelajaran siswa. Selain itu, mereka juga lebih mudah mendapatkan posisi manajemen dan sanggup bertahan di posisi tersebut karena mereka memiliki keterampilan untuk mengatasi kompleksitas manajemen organisasi (Davis \& Hammond, 2012). Berikut ini bagan program diklat penyiapan calon kepala sekolah yang efektif.

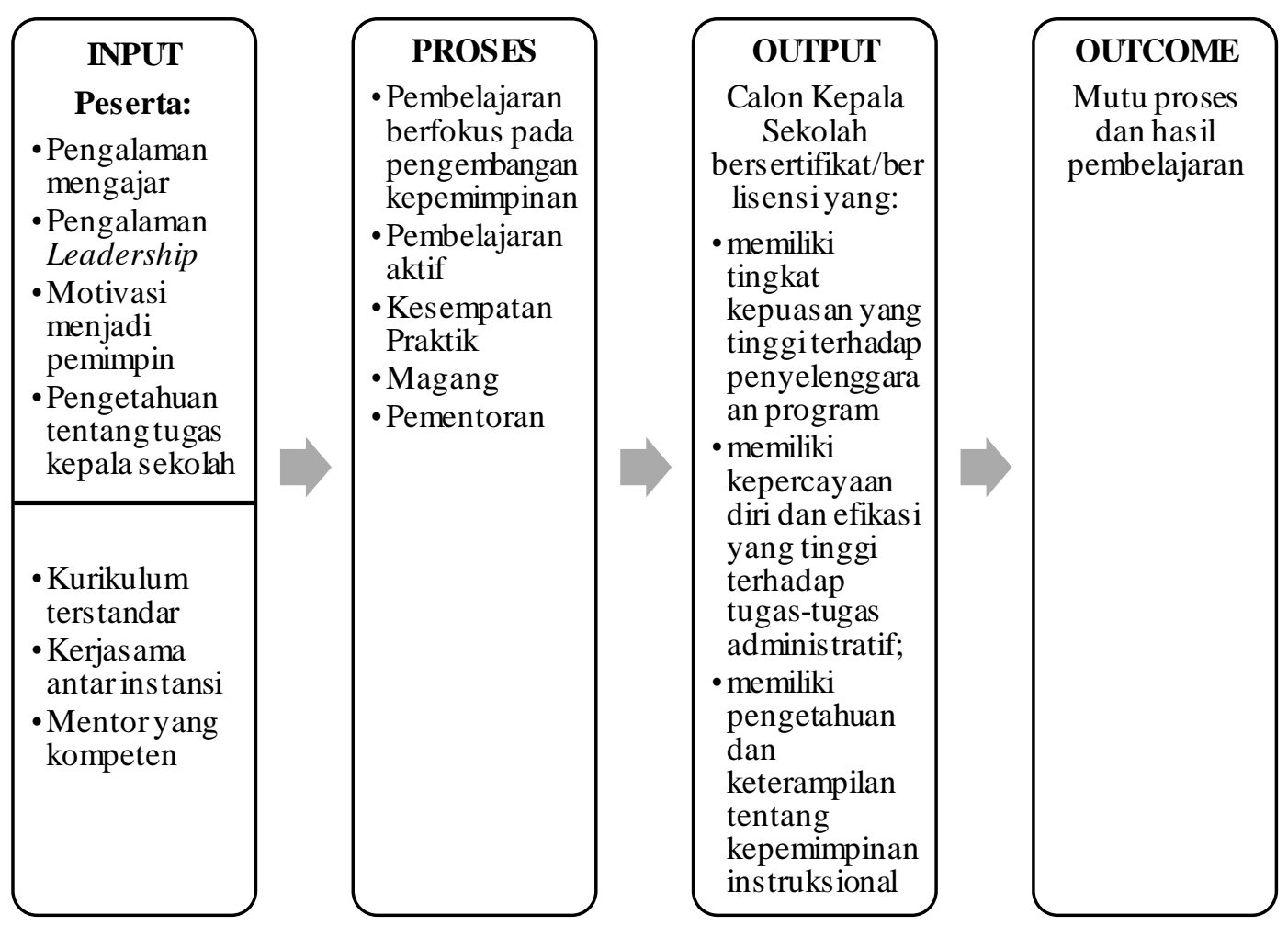

Gambar 1. Ba gan Program Penyiapan Calon Kepala Sekolah yang Efektif

\section{2 Program pendidikan dan pelatihan calon kepala sekolah (CKS) model in-on-in di}

\section{Indonesia}

Program diklatCKS di Indonesia merupakan rangkaian dari program penyiapan kepala sekolah setelah tahap seleksi. Program ini memberikan diklat kepada guru yang lolos seleksi administrasi dan akademik bakal CKS (Kementerian Pendidikan \& Kebudayaan, 2018). Diklat diarahkan pada penguasaan lima dimensi kompetensi utama kepala sekolah yaitu keprib adian, manajerial, kewirausahaan, supervisi dan sosial (Kementerian Pendidikan Nasional, 2007). Diklat berlangsung selama 300 jam belajar dengan menggunakan model in-service learning, on the job learning, dan in service learning 2.

- In-service learning 1 (ISL1)

ISL1 memberikan pengetahuan tentang kebijakan pendidikan di tingkat nasional dan kabupaten, manajemen sekolah, kepemimpinan, kewirausahaan, dan pengawasan 
akademik. Kegiatan ISL1 merupakan kegiatan tatap muka antara peserta diklat dengan nasrasumber/fasilitator dengan durasi minimal 70 jam pelajaran, di mana tiap satu jamnya adalah 45 menit. Pada sesi terakhir, peserta diklat diminta untuk menyusun rencana tindakan yang akan diimplementasikan pada saat OJL. Rencana tindakan tersebut disusun berdasarkan Analisis Kebutuhan Pengembangan Keprofesian (AKPK) dari masingmasing peserta diklat.

- On-the job learning (OJL)

$O J L$ memberikan pengalaman lapangan berkaitan dengan manajemen dan kepemimpinan melalui magang di sekolah sendiri dan sekolah lain. OJL ini merupakan pelaksanaan rencana tindakan yang telah disusun pada saat ISL1. OJL dilaksanakan melalui berbagai kegiatan nyata di dua tempat, yaitu: sekolah/madrasah sendiri dan sekolah/madrasah lain yang status kualitasnya lebih tinggi atau sama selama tiga bulan atau setara dengan 200 jam pelajaran.

- In-service learning 2 (ISL2)

In-2 memberikan kesempatan kepada calon kepala sekolah untuk melakukan refleksi dan evaluasi pengalaman belajarnya saat OJL. ISL2 dilaksanakan dalam durasi 30 jam pelajaran, di mana penilaian portofolio CKS dilakukan. Portofolio adalah sejumlah tagihan pelaksanaan OJL yang dikumpulkan oleh calon kepala sekolah/madrasah dalam satu folder. Penilaian juga dilakukan melalui presentasi hasil OJL dan refleksi terhadap pelaksanaan kegiatan tersebut untuk mengetahui ada tidaknya peningkatan kompetensi $\mathrm{CKS} / \mathrm{madrasah}$. 


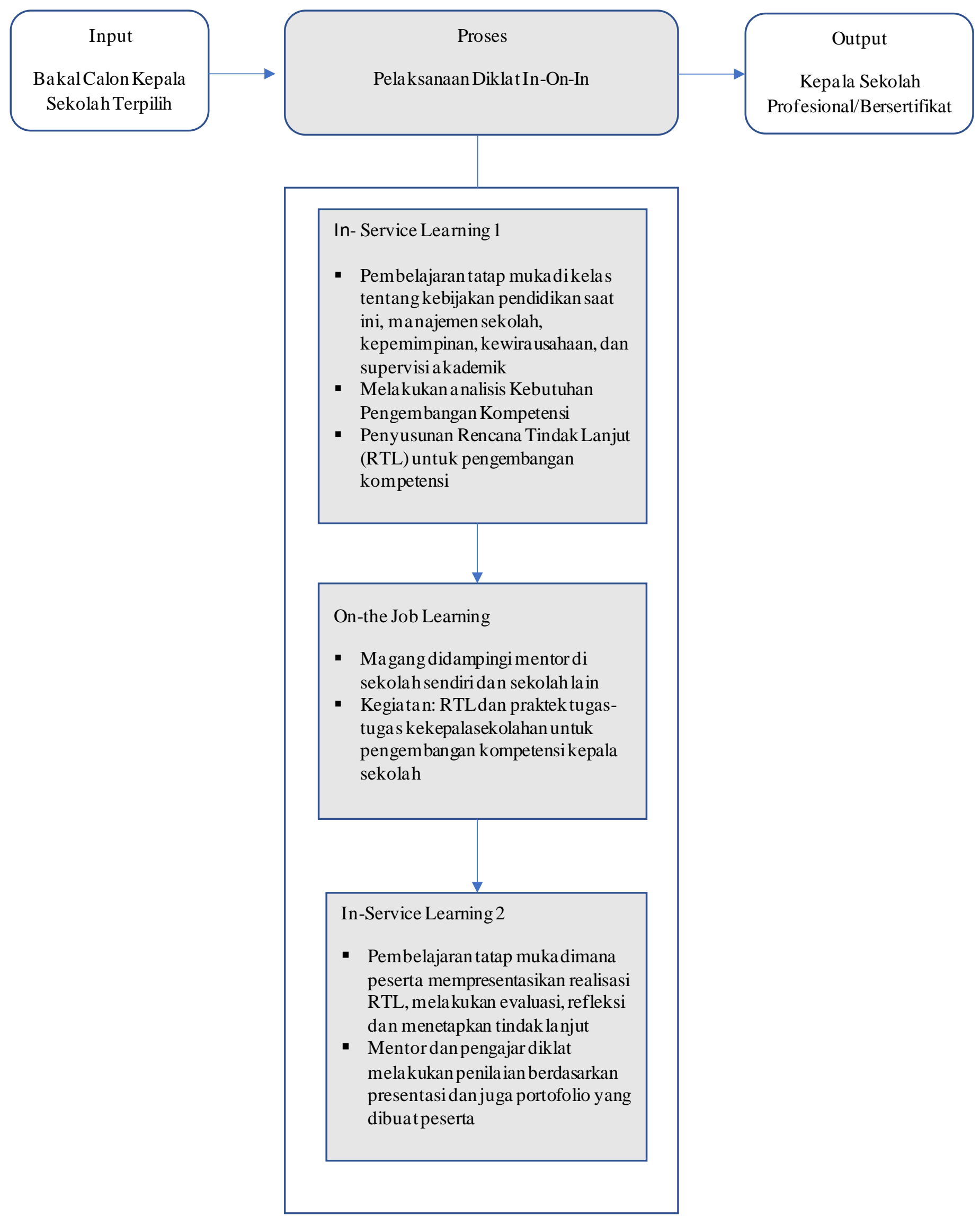

Gambar 2. Bagan Pelaksanaan DiklatCalon Kepala Sekolah Model In-On-In 
Model in-on-in dirancang untuk memberikan pengalaman belajar yang terpadu antara aspek pengetahuan kognitif dan pengalaman empirik sesuai dengan karakteristik peserta siklat sebagai adult learner (Kementerian Pendidikan \& Kebudayaan, 2013).

CKS yang dinyatakan lulus diklat akan diberi Surat Tanda Tamat Pendidikan dan Pelatihan Calon Kepala Sekolah yang ditandatangani oleh Direktur Jenderal. CKS yang dinyatakan tidak lulus diberi kesempatan untuk mengikuti kembali Pendidikan dan Pelatihan Calon Kepala Sekolah paling banyak dua kali. Surat Tanda Tamat Pendidikan dan Pelatihan Calon Kepala Sekolah ini merupakan salah satu syarat wajib mengikuti proses pengangkatan jabatan kepala sekolah/madrasah (Kementerian Pendidikan \& Kebudayaan, 2018).

\section{METODE PENELITIAN}

\section{1 Jenis penelitian}

Penelitian ini merupakan penelitian evaluasi kualitatif yaitu evaluasi program dengan pendekatan dan metode pengumpulan data kualitatif (Vaterlaus \& Higginbotham, 2011). Jenis penelitian ini sesuai dengan tujuan penelitian yaitu mengeksplorasi pandangan, kebutuhan, dan hasil suatu program baik yang diharapkan maupun tidak yang digunakan sebagai dasar pengembangan program yang lebih baik (Anastas, 2004). Ketika evaluasi kualitatif diarahkan untuk menggali informasi dari peserta pasca pelatihan, maka aspek-aspek dari suatu program pelatihan yang bermanfaat dan efektif untuk meningkatkan kinerja lulusan program dapat teridentifikasi (Kang, Moyle, Cooke, O’ Dwer, 2017)

Penelitian ini menggunakan paradigma interpretivism yang sesuai untuk evaluasi kualitatif (Greene, 1994) dan juga karakteristik pertanyaan penelitian yang membutuhkan metode penelitian yang memungkinkan peneliti untuk melakukan interpretasi terhadap suatu fenomena sosial (O’Donoghue, 2007). Interpretivism bertujuan mengungkap beragam makna yang diberikan orang pada situasi dan perilaku tertentu dalam konteks sosialnya (O'Donoghue, 2007; Schwartz-Shea \& Yanow, 2012). Interpretivism percaya bahwa pengalaman dan tindakan manusia memiliki makna dan tugas peneliti adalah menafsirkan makna dalamkonteks sosial mereka (Lincoln, Lynham \& Guba, 2011). Oleh karenanya, interpreter yang interpretivis diharapkan memahami konteks sosial dan budaya dimana data dihasilkan agar dapat memaknai data secara akurat (Lincoln et al., 2011).

Data dikumpulkan dan dianalisis dengan metode pengumpulan dan analisis data grounded theory yang konsisten dengan paradigma interpretivism (Corbin \& Strauss, 2008; Hennink, Hutter, \& Bailey, 2011). Metode ini bertujuan untuk membangun teori melalui pengumpulan dan analisis data yang sistematis, "theory therefore will be grounded in data" 
(Punch, 2014, p. 185). Dengan pendekatan ini, pengumpulan data dan analisis dilakukan beriringan (Charmaz, 2006; Corbin \& Strauss, 2008; Johnson \& Christensen, 2012) yang memungkinkan peneliti untuk memilih partisipan berdasarkan pada perkembangan konsep dan juga sebagai cara untuk memvalidasi konsep yang dihasilkan (Merriam, 2009).

\section{2 Subyek penelitian}

Subyek penelitian ini yaitu semua lulusan diklat CKS dengan model in-on-in tahun 2013. Mereka dipilih dengan teknik purposive sampling. Teknik ini memungkinkan peneliti memilih informan sesuai dengan tujuan penelitian. Saat penelitian ini dilaksanakan, lulusan diklat yang dilibatkan dalam penelitian ini telah menjabat sebagai kepala sekolah negeri baik SD, SMP, SMA maupun SMK di kabupaten/kota di Daerah Istimewa Yogyakarta. Pengalaman mereka mengikuti diklat CKS dan menjabat kepala sekolah yang membutuhkan pengetahuan dan keterampilan mengelola dan memimpin sekolah mendukung perolehan data yang relevanuntuk menjawab pertanyaaan penelitian ini.

\section{3 Metode pengumpulan data}

Data penelitian dikumpulkan dengan metode wawancara semi terstruktur. Metode ini memungkinkan semua pertanyaan ditanyakan secara fleksibel dan tidak terstruktur (Merriam, 2009) untuk mendapatkan informasi yang mendalam. Fleksibilitas disini meliputi sikap responsif peneliti terhadap apa yang dikatakan oleh informan, menindaklanjuti hal-hal yang menarik, merubah urutan pertanyaan, menindaklanjuti dan mencari kejelasan jawaban yang tidak konsisten (Bryman, 2013).

Studi dokumen juga dilakukan untuk mengkonfirmasi kebenaran informasi yang diperoleh melalui wawancara. Dokumen yang dikaji dalam penelitian ini meliputi berbagai naskah kebijakan dan peraturan terkait program penyiapan kepala sekolah di Indonesia dengan model in-on-in dan dokumen-dokumen berkaitan dengan pelaksanaan diklat CKS yang diikuti oleh kepala sekolah yang diwawancara.

\section{4 Instrumen penelitian}

Instrumen penelitian ini yaitu panduan wawancara berupa pertanyaan atau topik yang perlu digali oleh pewawancara. Panduan wawancara berisi pertanyaan-pertanyaan pokok dan yang terkait yang diarahkan untuk menjawan pertanyaan utama penelitian yang berkembang ketika panduan wawancara digunakan (Savin-Baden \& Major, 2013) 


\section{5 Teknik analisis data}

Data yang terkumpul dianalisis dengan teknik analisis data kualitatif yaitu metode analisis data grounded theory: open coding dilanjutkan dengan analytic induction. Open coding digunakan untuk menghasilkan label konseptual dan kategori untuk membangun teori yang sesuai dengan data (Johnson \& Christensen, 2012, Punch, 2009). Analytic induction digunakan untuk merumuskan pernyataan lengkap dan universal tentang suatu fenomena sosial (Sarantakos, 2005) yang dihasilkan dari proses open coding dengan cara mencari dan memperhitungkan kasus atau bukti negatif dalam data (Katz, 2001).

\section{6 Kualitas data}

Penelitian ini menggunakan kriteria trustworthiness (Savin-Baden \& Major, 2013) yang mencakup credibility, transferability, dependability, and confirmability (Ary et al., 2010; Lincoln \& Guba, 1985) untuk menjamin kualitas studi. Teknik peer review (Merriam, 2009) dengan dua orang kolega di bidang manajemen pendidikan digunakan dalam penelitian ini untuk memenuhi kriteria kredibilitas. Pemenuhan kriteria transferabilitas dilakukan dengan memberikan deskripsi yang memadai terkait proses dan konteks penelitian (Ary, et al., 2010; Schwartz-Shea \& Yanow, 2012). Aaudit trail digunakan untuk memenuhi kriteria dependabilitas dan konfirmabilitas (Flick, 2009; Lincoln \& Guba, 1985).

\section{HASIL}

\section{1 In-service learning 1}

3.1.1 Kurikulum diklat yang komperhen sif namun belum sepenuhnya relevan

Hasil penelitian menunjukkan bahwa kurikulum diklat CKS mencakup materi tentang kepemimpinan, manajemen dan administrasi sekolah, supervisi akademik, dan kewirausahaan. Kurikulum ini dipandang komprehensif karena membekali pengetahuan dan keterampilan yang peserta butuhkan saat menjabat kepala sekolah. Mereka mengatakan:

Program penyiapan CKS ini sangat menyeluruh. Pada tahap In-1 terdapat program kepemimpinan, kemudian kami diajarkan untuk merencanakan program sekolah (membuat rencana kerja tahunan, rencana kerja jangka menengah, dan rencana kerja jangka panjang). Kami juga mendapat materi manajemen sekolah supaya bisa meningkatkan kualitas sekolah dan prestasi siswa (W3.SU.2).

Diklat memberikan materi yang dibutuhkan seorang kepala sekolah yaitu kepemimpinan, kedisiplinan, kehati-hatian dalam mengambil keputusan, dan banyak lagi lainnya (W2.JU.9). 
Saat diklat in-on-in kami diajari hal-hal apa saja yang dapat dilakukan untuk menjadi kepala sekolah ideal. Jadi menurut saya program ini banyak memberi ilmu. Dari yang zero menjadi tahu, dari yang sedikit tahu menjadi lebih banyak tahu, dan yang sudah tahu menjadi the best (W1.AR.15).

Pernyataan-pernyataan tersebut menunjukkan bahwa kurikulum yang komperhensif bermanfaat untuk membantu mereka menguasai kompetensi kepala sekolah yang ditargetkan program. Selain itu, hasil studi dokumen menunjukkan proporsi yang cukup besar, lebih dari $50 \%$ dari total alokasi waktu ISL1 untuk materi yang berkaitan dengan keterampilan hubungan manusia yaitu: kepemimpinan spiritual, dinamika kelompok, kepemimpinan pembelajaran, dan supervisi akademik. Materi ini didesain untuk menguatkan kompetensi kepemimpinan

Namun demikian, mayoritas kepala sekolah dari semua jenjang pendidikan berpandangan bahwa materi tentang pemanfaatan teknologi informasi dan komputer untuk mempermudah pekerjaan mereka sehari-harinya sangat minim. Hasil studi dokumen menunjukkan bahwa keterampilan memanfaatkan teknologi tidak termasuk materi inti dalam diklat CKS. Selain itu, beberapa materi di ISL1 juga dipandang kurang relevan oleh kepala sekolah dasar. Mereka mengatakan:

Kami mendapatkan materi tentang penerimaan siswa baru, bagaimana melakukan seleksi. Ilmu tentang itu gak terpakai di sekolah kami yang mayoritas masyarakat kurang perduli pendidikan. Kami harus kunjungi rumah mereka untuk mendapatkan murid (W6.EL1).

Mereka juga mengungkapkan perlunya peningkatan relevansi kurikulum diklat dengan memberikan penekanan pada keterampilan praktis. Salah seorang kepala sekolah mengatakan:

Ketika in-1 itu kita diberi teori tentang kekepalasekolah yang bagus. Namun, kita tidak diberi ilmu praktis yang kekinian, misalnya tentang pengelolaan keuangan yang bersumber dari pemerintah pusat ataupun pemerintah daerah. Materi ini saya rasa penting karena saat sebagai kepala sekolah, kita harus memeprtanggungjawabkan dana tersebut. Pertanggungjawababan tidak main-main, berhubungan dengan hukum. kepala sekolah harus melaporkan ke Badan Pemeriksa Keuangan dan Inspektorat (W8.BB.7).

Lebih lanjut, mereka menyebutkan keterampilan-keterampilan praktis yang mereka pandang penting yang belum banyak diajarkan di ISL1. Keterampilan tersebut mencakup teknik supervisi yang efektif, cara membuat laporan keuangan yang sesuai dengan aturan pemerintah, strategi mengatasi guru-guru yang tidak disiplin atau kurang profesional dalam mengajar, dan strategi menyiapkan akreditasi sekolah. Salah satu kepala sekolah juga mengungkapkan perlunya materi norma agama dan budi pekerti. Ilmu pskologi juga dipandang penting untuk 
bisa memahami orang lain sehingga interaksi kepala sekolah dengan guru, siswa dan orang tua murid bisa efektif.

\subsubsection{Metode pembelajaran orang dewasa}

Metode yang digunakan ketika tahap ISL1 memanfaatkan pengalaman peserta dan mendorong keaktifan mereka. Salah seorang kepala sekolah mengatakan: .

Diklat yang saya ikuti saat itu ada 40 guru dari berbagai tingkat pendidikan: SD, SMP, SMA dan SMK. Kami diminta diskusi dan berbagi pengalaman. Diskusi ini memperkaya wawasan kami karena tiap sekolah memiliki potensi dan kendala yang berbeda-beda. LPPKS sifatnya memfasilitasi tema yang akan didiskusikan oleh calon kepala sekolah (W8.BB.7).

Pernyataan di atas dilengkapi oleh lulusan diklat yang lain sebagai berikut.

Program yang pernah saya ikuti ini menurut saya sudah sangat ideal. Disana ada teori, langsung praktik juga, ada permainan-permainan yang mengasah jiwa leadership, narasumber yang kompeten, kemudian ada outbound dimana kita dibentuk kelompok untuk menyelesaikan suatu masalah. Outbond ini ditujukan untuk mengasah jiwa kepemimpinan dan kerjasama tim (W6.EL1).

Pernyataan di atas menunjukkan bahwa tahap ISL1 telah menerapkan pembelajaran orang dewasa. Pembelajaran memanfaatkan pengalaman dan pengetahuan peserta. Peserta diberi kesempatan untuk berbagi pengetahuan dan saling membelajarkan. Metode pembelajaran yang diterapkan bervariasi. Luaran utama yang diharapkan dalam ISL1 yaitu rencana kegiatan yang berkaitan dengan tugas seorang kepala sekolah yang mereka realisasikan di sekolah dimana mereka melakukan $O J L$ yaitu di sekolah sendiri dan sekolah magang.

\section{2 On the job learning}

3. 2.1 Kesempatan mempraktekkan teori yang menguatkan penguasaan kompetensi kepala sekolah

OJL mengkondisikan peserta diklat untuk memperoleh pengalaman langsung pengelolaan dan kepemimpinan sekolah di dua sekolah yaitu sekolah sendiri dan di sekolah lain. Lulusan diklat mengungkapkan bahwa melalui OJL, mereka merealisasikan rencana kegiatan yang dibuat di ISL1 dan juga melaksanakan beberapa tugas kekepalasekolahan. Kegiatan tersebut mereka rasakan memberikan pengalaman penting terkait peran kepala sekolah dan membantu mereka menguasai kompetensi yang diharapkan. Mereka berkata:

Ketika OJL saya mempelajari dokumen-dokumen administrasi sekolah, kegiatankegiatan sekolah, membuat rencana kegiatan yang bisa meningkatkan kompetensi guru di sekolah. Pengalaman ini bermanfaat saat saya telah menjabat(W7.AM.11). 
Saat OJL, saya mengimplementasikan rencana kegiatan (RTL) yang saya buat di ISLI agar saya memiliki kompetensi kepala sekolah yang diharapkan. Saya juga mempelajari berbagai dokumen terkait keuangan, kesiswaan, kurikulum, program sekolah, dan lain-lain. Saya juga selalu berdiskusi dengan kepala sekolah terkait apa yang saya pelajari dan kegiatan yang saya lakukan. Pengalaman dan ilmu tersebut membuat saya terbantu untuk mampu menjalankan tugas saya sebagai kepala sekolah (W7.AM.11).

Ketika OJL saya juga dapat belajar tentang bagaimana mengelola, memimpin dengan kepala sekolah dari sekolah yang menjadi lokasi OJL, berdiskusi seperti itu" (W7.AM.11).

Saya dulu menjadi pembina upacara... (W6.EL.1).

Pernyataan-pernyataan di atas menunjukkan bahwa $O J L$ memberikan pengalaman lapangan yang membekali mereka pengetahuan dan keterampilan yang dibutuhkan. Pengalaman lapangan ini merupakan praktik atas berbagai kompetensi kepala sekolah yang dipelajari di ISL1 melalui realisasi rencana tindak lanjut. Dengan demikian, materi diklat koheren.

\section{2.2 Kualitas mentor yang belum terstandar}

Ketika melaksanakan OJL di sekolah sendiri dan juga di sekolah magang, peserta diklat CKS didampingi seorang mentor yaitu kepala sekolah di sekolah tersebut. Mentor bertugas memberikan arahan pelaksanaan kegiatan magang. Peran mentor sangat krusial dalam mewujudkan pementoran yang efektif. Kepala sekolah lulusan diklat mengatakan:

Mentor OJL saya sangat kompeten. Dia bisa menjelaskan apa yang harus dilakukan saya lakukan saat OJL dan mengarahkan saya dalam realisasi kegiatan (W5.NU.1).

Pernyataan tersebut diperkuat dengan pernyataan informan lain yaitu:

Penjelasan yang diberikan mentor terkait pelaksanaan RTL dan laporan $O J L$ sudah bagus. Mentor juga tanggap membantu saya ketika saya menghadapi hambatan. Saya terbantu dan terarah (W2.JU.9).

Kedua kutipan di atas menunjukkan bahwa pementoran di OJL telah dilaksanakan dengan baik.

Namun demikian, ada satu kepala sekolah yang mengungkapkan bahwa mentornya kurang kompeten. Akibatnya, proses dan hasil belajar di OJL ia rasakan kurang maksimal.

Mentor lapangan $O J L$ kurang menguasai materi pementoran. Contoh ia tidak paham bagaimana membuat laporan $O J L$. Saya jadi bingung. Kami sudah melaksanakan pertemuan berkali-kali tapi tidak efektif. Pelaksanaan OJL jadi tidak maksimal. Dia juga terlihat tidak paham saat mendampingi saya presentasi laporan di IST 2 (W7.AM.11) 
Ia menambahkan bahwa walaupun mentor tersebut $\mathrm{S} 1$, mentor tersebut tidak benar-benar memahami pembelajaran manajemen sekolah pada sesi OJL. Kondisi tersebut menunjukkan bahwa $O J L$ mungkin berjalan tidak sesuai harapan ketika mentor kurang kompeten.

\section{3 In-service learning 2}

Pada ISL2 peserta diklat berkewajiban melaporkan kegiatan dan hasil OJL kepada pengajar melalui presentasi dan portofolio. Peserta juga melakukan evaluasi dan refleksi atas apa yang telah dikerjakan sebagai dasar tindak lanjut kegiatan. Presentasi laporan OJL akan diberi masukan dan komentar dan penilaian oleh pengajar diklat dan mentor. Penilaian mencakup aspek sikap, keterampilan, dan portofolio.

Di ISL2 kita harus melaporkan dan mempresentasikan apa yang sudah dilakukan, kita akan mendapatkan pertanyaan dari peserta lain dan pengajar (W4.BU.3).

ISL2 kita mempresentasikan hasil laporan(W6.EL.1).

Namun, dalam pelaksanaan ISL2 ini, salah seorang lulusan mengungkapkan bahwa ia tidak puas dengan tanggapan yang disampaikan oleh pengajar. Lulusan tersebut berkata:

Waktu presentasi terbatas... selain itu satu dari dua pengajar sibuk saat itu. Jadi perhatian dan pemberian umpan balik tidak maksimal (W8.BB.7).

Kondisi di atas menunjukkan bahwa kualitas pembelajaran ISL2 yang memberikan penekanan pada kemampuan mengevaluasi, melakukan refleksi dan membuat tindak lanjut suatu kegiatan dipengaruhi salah satunya oleh komitmen pengajar diklat.

\section{PEMBAHASAN}

\section{1. In-service learning (ISL1)}

Hasil penelitian menunjukkan bahwa kurikulum diklat CKS model in-on-in pada tahap ISL1 yang utamanya mengajarkan tentang kepemimpinan sekolah, manajemen sekolah dan administrasinya, serta supervisi akademik dipandang komprehensif . Kurikulum memberikan pengetahuan dan keterampilan yang dibutuhkan peserta saat menjabat kepala sekolah. Selain itu, materi berkaitan dengan pengembangan kompetensi kepemimpinan sekolah mendapatkan porsi yang cukup besar di ISL1, lebih dari 50\%. Pengembangan kurikulum diklat tersebut senada dengan tren internasional tentang pengembangan kurikulum diklat penyiapan calon kepala sekolah di berbagai negara seperti Kanada, Australia, Singapura, dan Hongkong yang 
memberikan penekanan pada kompetensi kepemimpinan daripada manajemen (Walker, Bryant, \& Lee, 2013).

Hasil studi menunjukkan bahwa model kepemimpinan yang diajarkan menekankan pada model kepemimpinan instruksional. Penekanan model kepemimpinan instruksional ini selaras dengan materi ajar diklat penyiapan kepala sekolah yang dikembangkan di berbagai negara maju, khususnya Amerika Serikat (Davis \& Hammond, 2012; Klottersmanm, 2015). Di negara tersebut, program penyiapan kepala sekolah memberikan penekanan pada pembentukan kompetensi kepemimpinan instruksional atau pengajaran daripada sekedar kompetensi mengelola sekolah. Penekanan pada pengajaran juga telah dikemukakan hampir dua puluh tahun yang lalu oleh Gene, et al. (2003). Mereka mengatakan bahwa PPKS perlu memberikan materi terkait kurikulum, pengajaran dan strategi untuk menghasilkan prestasi siswa yang tinggi. Materi lain yang dipertimbangkan penting yaitu pengembangan organisasi dan manajemen perubahan (Davis \& Hammod, 2012).

Model kepemimpinan spiritual juga menjadi salah satu materi ajar inti diklat CKS. Kepemimpinan spiritual ini relevan untuk diajarkan mempertimbangkan karakter kepala sekolah Indonesia yang diharapkan, yang salah satunya yaitu beriman kepada Tuhan YME (Kementerian Pendidikan Nasional, 2007). Kepala sekolah akan memimpin warga sekolah yang umumnya religius karena mayoritas bangsa Indonesia beragama. Dengan demikian, kepemimpinan spiritual yang esensinya merupakan kepemimpinan yang membawa dimensi keduniawian kepada dimensi spiritual, lebih banyak dibimbing oleh faktor internal yaitu hati nuraninya, berbasis pada etika religius seperti kejujuran sejati, fairness, semangat beramal sholeh, membenci agama sebagai formalitas, sedikit bicara banyak bekerja, mengupayakan yang terbaik bagi diri sendiri dan orang lain, dan terbuka pada perubahan (Tobroni, 2010) dibutuhkan. Hasil studi Raihani \& Gurr(2006) dan Raihani (2008) menguatkan hal ini. Mereka menemukan bahwa nilai-nilai agama seperti amanah, iman dan taqwa melandasi kepemimpian kepala sekolah Indonesia yang berhasil. Namun demikian, model kepemimpinan spiritual ini tidak ditemukan sebagai salah satu materi inti diklat CKS di banyak negara barat meskipun hal ini telah mendapatkan kritik (Lumby \& English, 2009).

Hasil penelitian juga menunjukkan bahwa kurikulum diklat CKS perlu memberikan alokasi waktu untuk materi yang berkaitan dengan teknologi informasi. Materi tentang ini sangat dibutuhkan oleh peserta. Selain perkembangan ipteks, kebutuhan ini nampaknya juga dipicu oleh pengembangan besar-besaran pembelajaran dan administrasi sekolah berbasis teknologi informasi dan komunikasi (TIK) oleh pemerintah pusat sejak awal tahun 2000-an (Departemen Pendidikan Nasional, 2007; Ministry of Education \& Culture 2013; Ministry of 
National Education, 2011). Dengan demikian, pembelajaran tentang TIK perlu diberikan. Untuk menguatkan penguasaan keterampilan ini, hasil riset program penyiapan kepala sekolah Kentucky di Amerika Serikat menyarankan perlunya pengalaman lapangan berkaitan dengan keterampilan ini (Dodson, 2014).

Selain itu, diklat juga perlu memberikan materi yang berisi keterampilan praktis seperti teknik supervisi yang efektif, cara membuat laporan keuangan yang sesuai dengan aturan pemerintah, strategi mengatasi guru-guru yang tidak disiplin atau rendah komitmen kerjanya, dan strategi menyiapkan akreditasi sekolah. Mendukung kebutuhan tersebut, hasil riset mengungkapkan bahwa kurikulum program penyiapan kepala sekolah yang berkualitas lebih menekankan pada pengembangan keterampilan-keterampilan yang paling dibutuhkan peserta ketika menjabat kepala sekolah, misalnya bagaimana menjadi pemimpin instruksional, bagaimana memberikan feedback pada kinerja guru disertai kesempatan kepada mereka untuk mempraktikkannya (Wallace, 2016). Hal ini membutuhkan pemutakhiran kurikulum agar relevan dengan tugas pekerjaan dan tanggung jawab pemimpin sekolah saat ini. Lebih lanjut, hasil riset menyarankan pentingnya pengalaman lapangan berkaitan dengan materi-materi diklat yang diajarkan (Davis \& Hammond, 2012; Dodson, 2014; Wallace, 2016).

Hasil penelitian juga menunjukkan bahwa metode pembelajaran telah memanfaatkan pengalaman peserta dan juga mendorong keaktifan mereka melalui kegiatan diskusi dan berbagi pengalaman. Hasil penelitian ini selaras dengan hasil penelitian PPKS di berbagai negara bagian di Amerika Serikat (Davis \& Hammond, 2012). Hasil riset menyarankan penerapan pembelajaran orang dewasa yang banyak memanfaatkan pengalaman peserta, pembelajaran berbasis masalah dan otentik.

\section{2. On-the job learning (OJL)}

Hasil penelitian menunjukkan bahwa OJL memberikan kesempatan kepada peserta diklat untuk mempraktikkan teori yang diperoleh saat magang atau ISL1 di dua sekolah: sekolah dimana ia mengajar dan di sekolah lain. Mereka mempraktikkan manajemen melalui realisasi rencana kegiatan/rencana tindak lanjut dan juga melakukan tugas-tugas kepala sekolah, misalnya menjadi pembina upacara, mengerjakan administrasi sekolah, mengkoordinir kegiatan sekolah, dan sebagainya. Pengalaman lapangan ini menguatkan kompetensi kepala sekolah yang peserta wajib kuasai. Hasil penelitian ini selaras dengan hasil penelitian program penyiapan kepala sekolah yang berhasil (Daresh, 1997; Davis \& Hammond, 2012; Dodson, 2014; Gene, et al., 2003). 
Pengalaman lapangan, misalnya magang, merupakan salah satu elemen penting program penyiapan kepala sekolah (Davis \& Hammond, 2012). Magang sebaiknya penuh waktu agar efektif. Artinya, peserta diklat yang umumnya guru dibebaskan sementara dari tugas mengajarnya (Gene, et al., 2003). Kegiatan lapangan yang perlu dilakukan agar magang efektif antara lain mengobservasi dan melaksanakan tugas-tugas kepemimpinan sekolah seperti pembuatan keputusan berbasis sekolah, pemecahan masalah terkait dengan kurikulum dan pembelajaran, pengelolaan anggaran dan keuangan sekolah, serta kesempatan melakukan pekerjaan sehari-hari kepala sekolah (Dodson, 2014; Gene, et al., 2003). Peserta hendaknya diberi kesempatan untuk memilih pengalaman lapangan yang dia butuhk an dengan kepala sekolah dimana dia melaksanakan magang (Davis \& Hammond, 2012, Dodson, 2014).

Hasil penelitian juga menunjukkan bahwa OJLini dirasakan efektif ketikamentor dapat memberikan arahan dan bimbingan yang dibutuhkan peserta program. Hasil sebaliknya terjadi ketika mentor tidak mampu melaksanakan tugasnya dengan baik. Hasil penelitian ini mendukung hasil penelitan sebelumnya yang menyarankan bahwa program membutuhkan mentor yang kompeten. Idealnya mereka individu yang berpengalaman dan juga berprestasi di bidang manajemen sekolah (Daresh, 1997; Davis \& Hammond, 2012, Dodson, 2014) misalnya kepala sekolah berprestasi (Gene, et al., 2003) atau akademisi yang berpengalaman menjadi kepala sekolah yang berhasil (Wallace, 2016).

Pementoran juga perlu didesain dengan baik. Proses pementoran hendaknya terstandar dengan standar capaian yang tinggi. Perencanaan pementoran sebaiknya berkolaborasi dengan pihak-pihak yang berkepentingan. Dengan demikian, di Indonesia, Lembaga Pengembangan dan Pemberdayaan Kepala Sekolah (LPPKS) perlu bekerja sama dengan Dinas Pendidikan Kabupaten dan Propinsi. Selain itu, pembelajaran hendaknya berbasis masalah, pembagian tugas dan tanggung jawab mentor, pengawas, dan koordinator program magang jelas, serta evaluasi kinerja mentor bermakna (Gray, Fry, Bottoms, \& O'Neill, 2007). Oleh karenanya, magang perlu dikelola oleh praktisi profesional yang memiliki pengetahuan, waktu dan komitmen untuk menjamin CKS benar-benar mendapatkan pengalaman yang banyak dan bermakna yang memungkinkan mereka mengembangkan kompetensi kepemimpinannya saat magang (Gray, et al., 2007). Hal ini membutuhkan seleksi dan pelatihan untuk mentor serta kejelasan peran yang diharapkan dari mereka dalam proses pementoran.

\section{3. In-service learning 2 (ISL2)}

Hasil penelitian menunjukkan bahwa ISL2 telah mendorong peserta diklat CKS untuk melakukan evaluasi dan refleksi pelaksanaan dan hasil kegiatan yang dilaksanakan pada $O J L$ 
serta merumuskan rencana tindak lanjut yang diperlukan. Praktik kepemimpinan disertai kegiatan refleksi atas apa yang telah dilakukan merupakan salah satu komponen penting program penyiapan kepala sekolah, khususnya komponen magang (Wallace, 2016).

Mentor bersama dengan pengajar diklat yang telah mengajar di ISL1 melakukan penilaian capaian kompetensi CKS berdasarkan presentasi dan laporan kegiatan peserta diklat selama OJL. Hasil studi menyarankan bahwa penilaian hendaknya berbasis kinerja yang menilai capaian kompetensi dan kesiapan peserta menjadi kepala sekolah. Oleh karenanya, kinerja magang/pementoran yang diharapkan hendaknya dikomunikasikan oleh mentor kepada CKS sejak awal (Gray, et al., 2007).

\section{SIMPULAN}

Pengembangan program diklat CKS di Indonesia senada dengan tren program penyiapan kepala sekolah di berbagai negara. Kurikulumnya komperhensif dan koheren antara aspek pengetahuan dengan pengalaman empiris yang dikemas melalui ISL1, OJL dan ISL2. Diklat juga telah menerapkan pendekatan pembelajaran orang dewasa sebagai strategi pembelajaran dan mengevaluasi tingkat penguasaan kompetensi peserta diklat. Model diklat tersebut dirasakan lulusan mendukung penguasaan kompetensi kepala sekolah yang mereka butuhkan. Namun demikian, hasil evaluasi juga menunjukkan bahwa masih terdapat beberapa aspek dari komponen diklat yang perlu ditingkatkan. Aspek tersebut yaitu: relevansi kurikulum dengan tugas pekerjaan dan tanggung jawab kepala sekolah saat ini serta kualitas mentor dan pementorannya di fase OJL. Perbaikan pada aspek komponen-komponen program yang masih lemah tersebut akan meningkatkan kualitas PPKS di negara ini.

\section{DAFTAR PUSTAKA}

Abu-Duhou, I. (1999). School-based management. Paris: Unesco, International Institute for Educational Planning.

Anastas, J. W., (2004). Quality in qualitative evaluation: issues and possible answers. Research on Social Work Practice, 14(1), 7-65.

Andriani, D. E. (2017). Leadership at the primary school level in Indonesia: A study of the historical background, recent developments, and current concerns of school leaders in a postcolonial and developing country. Doctoral Thesis. Perth: The University of Western Australia.

Ary, D., Jacobs, L. C., \& Sorensen, C. (2010). Introduction to research in education (8th ed.). Belmont, CA: Wadsworth CENGAGE Learning.

Barbour, J. D., (2005). Non-university-based principal preparation programs: analysis and disscussion of findings. A paper presented at the University Council for Educational Administration, Convenia, November 1-13, 2005. 
Bryman, A. (2013). Social research methods (4th ed.). Oxford: Oxford University Press.

Bush, T. (2007). Educational leadership and management: theory, policy, and practice. South African Journal of Education, 27(3), 391-406.

Bush, T., \& Glover, D. (2003). School leadership: Concepts and evidence. Nottingham: National College for School Leadership.

Charmaz, K. (2006). Constructing grounded theory: a practical guide through qualitative analysis. London: SAGE.

Corbin, J., \& Strauss, A. (2008). Basics of qualitative research. Thousand Oaks, CA: Sage.

Cranston, N. C. (2001). Collaborative decision-making and school-based management: challenges, rhetoric and reality. Journal of Educational Enquiry, 2(2), 1-24.

Daresh, J. C. (1997). Improving principal preparation: A review of common strategies. NASSP Bulletin, 81(585), 3-8.

Davis, H. D., \& Hammond, L. D., (2012). Innovative principal preparation programs: what works and how we know. Planning and chaning, 43(1), 25-45.

Delaney, J. G. (1997). Principal Leadership: A Primary Factor in School-Based Management And School Improvement. NASSP Bulletin, 81(586), 107-111. doi:10.1177/019263659708158613

Departemen Pendidikan Nasional. (2007). Sebuah laporan capaian kinerja. Jakarta: Departemen Pendidikan Nasional.

Dodson, R. L. (2014). Which field experiences best prepare future school leaders? An analysis of Kectuckky's principal preparation progra. Educational Research Quartely, 37(4), 41-6.

Fry, B., O'Neill, K., \& Bottoms, G. (2006). Schools can't wait: Accelerating the redesign of university principal preparation programs. Atlanta, GA: Southern Regional Education Board.

Gene, B., O’ Neill, K., Betty, F., David, H., (2003). Good principals are the key to successful schools: six strategies to prepare more good principals. Atlanta: Southern Regional Education Board.

Greene, J. C. (1994). Qualitative program evaluation. In N. K. Denzin \& Y. S. Lincoln (Eds.), Handbook of qualitative research (pp. 517-530). Thousand Oaks: SAGE Publications.

Hennink, M., Hutter, I., \& Bailey, A. (2011). Qualitative research methods. Los Angeles, California, London: SAGE.

Johnson, B., \& Christensen, L. (2012). Educational research quantitative qualitative, and mixed approaches. California: Sage Publication, Inc.

Kang, Y., Moyle, W., Cooke, M., O’ Dwyer., (2017). Qualitative evaluation of a delirium prevention and management programme. Journal of Clinical Nursing, 1-9.

Katz, J. (2001). Analytic induction. In N. J. Smelser \& P. B. Baltes (Eds)., International encyclopedia of the social and behavioural sciences (pp. 480-484). Oxford, UK: Elsevier.

Kementerian Pendidikan \& Kebudayaan (2013). Petunjuk Pelaksanaan: Pendidikan dan Pelatihan Calon Kepala sekolah/ Madrasah.

Kementerian Pendidikan dan Kebudayaan. (2018). Peraturan Menteri Pendidikan dan Kebudayaan Nomor 6, Tahun 2018, tentang Penugasan Guru sebagai Kepala Sekolah/Madrasah. Jakarta: Kementerian Pendidikan dan Kebudayaan.

Kementerian Pendidikan Nasional. (2007). Peraturan Menteri Pendidikan NasionalNomor 13, Tahun 2007, tentang Standar Kepala Sekolah/Madrasah. 
Kementerian Pendidikan Nasional. (2011). Petunjuk pelaksanaan diklat calon kepala sekolah/madrasah. Jakarta: Kementerian Pendidikan Nasional BPSDM dan PMP LPPKS.

Klostermann, B. K., Pareja, A. S., Hart, H., White, B. R., \& Huynh, M. H. (2015). Restructuring principal preparation in Illinois: Perspectives on implementation successes, challenges, and future outlook (IERC 2015-3). Edwardsville, IL: Illinois Education Research Council at Southern Illinois University

Leithwood, K., Harris, A., \& Hopkins, D. (2008). Seven strong claims about successful school leaderhip. School Leadership \& Management: Formerly School Organization, 28(1), 22-42.

Lincoln, Y. S., \& Guba, E. G. (1985). Naturalistic inquiry. Beverly Hills, CA: Sage Publications.

Lincoln, Y. S., Lyynham, S. A., \& Guba, E. G. (2011). Paradigmatic controversies, contradictions, and emerging confluences, In N. K. Denzin \& Y. S. Lincoln (Eds.), The Sage handbook of qualitative research. (4th ed., pp. 97-128). Thousand Oaks, CA: Sage.

Lumby, J., \& English, F. (2009). From simplicism to complexity in leadership identity and preparation: Exploring the lineage and dark secrets. International Journal of Leadership in Education, 12, 95-114.

Merriam, S. B. (2009). Qualitative research a guide to design and implementation. San Fransisco, CA: John Wiley \& Sons, Inc.

Ministry of Education and Culture. (2013). Overview of the education sector in Indonesia 2012. Achievement and challenges. Jakarta: Ministry of Education and Culture.

Ministry of National Education. (2011). The Indonesian basic education. Road to Education for All. Jakarta: Ministry of National Education.

O'Donoghue, T. (2007). Planning your qualitative research project. An introduction to interpretive research in education. London: Routledge.

OECD/Asian Development Bank. (2015). Education in Indonesia: Rising to the challenge. Paris: OECD Publishing.

Oplatka, I., (2009). A historical overview of scholarly attempts to recognize epistemological identities, meanings and boundaries from the 1960s onwards. Journal of Educational Administration, 47(1), 8-35.

Papalewis, R. (2005). The discipline of educational administration: Creditting the past. In T. Creighton, S. Harris, \& J.C. Coleman (Eds), Creditting the past, challenging the present, creating the future (pp. 5-22). Flagstaff, AZ: National Council of Professors of Educational Administration.

Punch, K. F. (2009). Introduction to research methods in education. London: SAGE.

Punch, K. F. (2014). Introduction to social research quantitative \& qualitative approaches (3rd ed.). Los Angeles, CA: Sage.

Raihani (2008). An Indonesian model of scucessful school ledership. Journal of Educational Administration, 46(4), 481-496. Doi: 10.1108/09578230810882018

Raihani \& Gurr, D. (2006). Value-Driven School Leadership: An Indonesian Perspective. Leading and Managing, 12(1), pp. 121-134.

Sarantakos, S. (2005). Social research (3rd ed.). New York: Palgrave Macmillan. 
Savin-Baden, M., \& Major, H. C. (2013). Qualitative research the essential guide to theory and practice. London: Routledge.

Gray, C., Fry, B., Bottoms, G., \& O'Neill, K. (2007). Good principals aren't born. They're mentored: Are we investing enough to get the school leaders we need?. Atlanta: SREB.

Schwartz-Shea, P., \& Yanow, D. (2012). Interpretive research design concepts and processes. New York: Routledge.

Suharsimi, A., \& Cepi, A. (2007). Evaluasi program pendidikan. Pedoman teoritis praktis bagi praktisi pendidikan. Jakarta: Bumi Aksara.

Sumintono, B., Sheyoputry, E. Y. A., Jiang, N., Misbach, I. H., \& Jumintono. (2015). Becoming a principal in Indonesia: possibility, pitfalls and potentials. Asia Pacific Journal of Education, 25(3), 342-352.

The Education Sector Analytical and Capacity Development Partnership. (2013). School and madrasah principals and supervisors competencies baseline study. Retrieved from https://www.adb.org/publications/school-and-madrasah-principals-and-supervisorscompetency-baseline-study

Tobroni (2010). The Spiritual Leadership (Pengefektifan Organisasi Noble Industry melalui Prinsip-prinsip Spiritual). Cet 2. Malang: UMM Press.

Vaterlaus, J. Mich. (2011). Qualitative Program Evaluation Methods. Tersedia online: https://projects.ncsu.edu/ffci/publications/2011/v16-n1.../vaterlaus-higginbotham.p. Diakses 10 Januari 2018.

Walker, A., Bryant, D., \& Lee, M. (2013). International patterns in principal preparation: Commonalities and variations in pre-service programmes. Educational Management Administration \& Leadership, 41(4), 405-434.

Wallace Foundation (2016). Improving university principal preparation programs. Five themes from the field. New York: The Wallace Foundation. 